\title{
Native predators contribute to invasion resistance to the non-indigenous bivalve Musculista senhousia in southern California, USA
}

\author{
Thorsten B. H. Reusch* \\ Biology Department, San Diego State University, San Diego, California 92182-4614, USA
}

\begin{abstract}
As one component of invasion resistance, native predators may consume non-indigenous species in the invaded habitat. I studied the contribution of predation to mortality in populations of a potentially dominant, habitat-modifying mussel (Musculista senhousia) which has been introduced from Asia to California. In short-term ( 2 to $4 \mathrm{wk}$ ) experiments performed in San Diego Bay, a muricid snail (Pteropurpura festiva) decimated transplanted mussel populations by up to $65 \%$ within 2 wh. Crustacean predators were responsible for mortality rates of $<4 \%$. The experimental removal of byssal cocoons in $M$. senhousia did not increase the susceptibility of the mussel to predation compared to unmanipulated individuals. In all experiments, predation was more intense inside an eelgrass (Zostera marina) bed compared to either unvegetated clearings or to sand flats adjacent to the eelgrass bed. In a 4 mo predator exclusion experiment, mussel numbers were reduced by $95 \%$ in the eelgrass compared to a decimation of only 36 and $50 \%$ on the unvegetated sand flat above and below the $Z$. marina bed, respectively. An aquarium experiment revealed that $P$. festiva favored $M$. senhousia over an abundant native clam in San Diego Bay, Chione undatella. In southern California, predation contributes significantly to the resistance of the recipient community to invasion and may locally prevent $M$. senhousia from establishing dense, habitat-modifying beds with potential effects on native infauna and eelgrass.
\end{abstract}

KEY WORDS: Biological invasion - Community ecology - Ecological resistance - Non-indigenous species $\cdot$ Musculista senhousia $\cdot$ Predation $\cdot$ Pteropurpura festiva $\cdot$ Zostera marina

\section{INTRODUCTION}

Whether or not introduced species can establish themselves and proliferate in their new environment depends not only on suitable physico-chemical conditions but also on biological interactions with the members of the recipient community (Pimm 1989, Vermeij 1991, Lodge 1993). Native predators may use nonindigenous species as new prey items and prevent them from becoming dominant in the invaded community (Suter 1982, Robinson \& Wellborn 1988, Case 1991, Baltz \& Moyle 1993, Trowbridge 1995). Among

\footnotetext{
- Present address: Dept Marine Biology, Biological Centre, University of Groningen, PO Box 14, 9750 AA Haren, The Netherlands. E-mail: t.reusch@biol.rug.nl
}

the many marine invasive species, the endobenthic mussel Musculista senhousia Benson in Cantor 1842 has recently received a lot of attention due to its potential to alter the soft-bottom habitat (Willan 1987, Creese et al. 1997, Crooks 1998, Reusch \& Williams 1998 , in press). $M$. senhousia was introduced to California in the 1960s and became abundant in the mid 1980s (Dexter 1983, MacDonald et al. 1990). It is now the most abundant macrobenthic invertebrate in terms of biomass at some sandy to muddy sites in Mission and San Diego Bay (Crooks 1992, Reusch 1996). The introduced bivalve forms beds with biomasses up to $1200 \mathrm{~g}$ dry mass $\mathrm{m}^{-2}$, corresponding to densities of $15000 \mathrm{~m}^{-2}$ (author's unpubl. data). M. senhousia constructs ovoid cocoons made of a matrix of byssal threads and ambient sediment which are supposed to protect the thin shell (Morton 1974). If a critical abun- 
dance (between 300 and $400 \mathrm{~g}$ dry mass $\mathrm{m}^{-2}, \approx 1500$ ind. $\mathrm{m}^{-2}$ ) is exceeded, individual byssal cocoons fuse to form continuously byssal carpets (Reusch 1996). Such habitat alteration through $M$. senhousia beds has profound effects on the native infauna (Morton 1974. Willan 1987, Crooks 1992, Creese et al. 1997, Crooks 1998), and on native eelgrass (Reusch 1996, Reusch \& Williams 1998;

The worldwide invasion success of Musculista senhousia is striking. Native to East Asia, M. senhousia has been introduced to New Zealand, Australia, the Mediterranean Sea and the Pacific coast of the U.S. (Carlton 1979 Willan 1985, Slack-Smith \& Brearley 1987. Hoenselaar \& Hoenselaar 1989). M. senhousia is thought to live at most $2 \mathrm{yr}$ (Crooks 1992, 1996) and attains a maximal size of $34 \mathrm{~mm}$ in San Diego Bay (author's unpubl. obs.).

The experiments presented in this study were prompted by observations from San Diego Bay suggesting that predators, in particular the muricid snail Pteropurpura festiva, may have significant effects on the distribution of Musculista senhousia. $P$. festiva is a relatively large muricid snail ( $\leq 65 \mathrm{~mm}$ length) common in sandy to muddy embayments from Santa Barbara to Baja California (McLean 1978), where it preys on shallow-burrowing bivalves such as Protothaca staminea and Chione undatella (Peterson 1982). In a series of experiments designed to assess the potential effects of $M$. senhousia on native eelgrass (Reusch \& Williams 1998), snails quickly aggregated in large $\left(0.5 \mathrm{~m}^{2}\right)$ transplanted mussel patches, attaining abundances $40 \times$ higher than ambient. Surprisingly, no $P$. festiva aggregations were observed outside the continuous eelgrass bed where experimental mussel populations persisted, indicating that the presence of an eelgrass bed modified the predation pressure on $M$. senhousia.

The objectives of this study were to (1) to quantify short-term mortality rates of Musculista senhousia through Pteropurpura festiva and other predators, (2) to assess the effects of the presence or absence of $M$. senhousia's byssal bags on predation mortality of the mussel, (3i to compare predation mortality inside and outside eelgrass beds, (4) to determine $M$. senhousia survival rates with and without predators in a predator exclusion experiment, and (5) to determine the prey preference of Pteropurpura festiva between $M$. senhousia and a native bivalve

\section{MATERIAL AND METHODS}

Mortality rate experiments (MRE) to assess per capita mortality rates of Musculista senhousia. All field observations and experiments were conducted in the shallow subtidal zone of San Diego Bay, California, a highly modified $22.5 \mathrm{~km}$ long embayment which is fully marine and completely sheltered from oceanic swells and has a mean tidal range of $1.5 \mathrm{~m}$. Experiments were conducted by means of SCUBA, preferentially at high tide. In order to estimate sources of mortality in $M$. senhousia, in particular the contribution of predation to $M$. senhousia mortality on a per capita basis, adult $M$. senhousia were transplanted for 2 to $4 \mathrm{wk}$ to replicated locations at 2 subtidal sites (MRE; Table 1). Experiments were conducted at Harbor Island ( $\mathrm{HI}, 32^{\circ} 43.3^{\prime} \mathrm{N}, 117^{\circ} 11.2^{\prime} \mathrm{W}$ ), at a depth of 0.8 to $3.5 \mathrm{~m}$ below MLW (mean low water), and at Le Meridien (LM, $32^{\circ} 41.4^{\prime} \mathrm{N}, 117^{\circ} 09.5^{\prime} \mathrm{W}$ ) at $1.5 \mathrm{~m}$ to $3 \mathrm{~m}$ below MLW. The sediments of both sites consist predominately of sand ( $>85 \%$ of grain size $>0.063 \mathrm{~mm}$ ).

Experimental plots covered an area of $300 \mathrm{~cm}^{2}$ and were surrounded by a ring made of polyethylene mesh fabric (mesh size $6 \mathrm{~mm}$ ) buried completely to a depth of $8 \mathrm{~cm}$ to facilitate mussel recovery.

To address differences in mussel mortality rates between unvegetated habitats and eelgrass Zostera marina beds, half of the experimental units were located inside an eelgrass bed ( 1 to $2 \mathrm{~m}$ depth, $>2 \mathrm{~m}$ away from any unvegetated area) and half were placed in 1 to $3 \mathrm{~m}$ wide clearings without vegetation (factor 'clearing vs eelgrass bed'). In MRE 4, the plots were either located within the eelgrass bed or on the adjacent sand flat at least $2 \mathrm{~m}$ away from the vegetation edge, which was deeper than the eelgrass bed at LM in 3 to $3.5 \mathrm{~m}$ depth and shallower than the continuous eelgrass bed at $\mathrm{HI}$ in 0.5 to $0.8 \mathrm{~m}$ depth (factor 'inside/outside eelgrass bed'). Eelgrass shoot densities ranged from 240 to 600 shoots $\mathrm{m}^{-2}$, and shoot heights ranged from 50 to $85 \mathrm{~cm}$ during the study period.

Mussels were gathered from HI in their natural size distribution and 15 individuals (size range 12 to $30 \mathrm{~mm}$ ) were transplanted in their natural upright position into the central $200 \mathrm{~cm}^{2}$ portion of the circular experimental plot. The resulting abundance of -800 ind. $\mathrm{m}^{-2}$ is in the low to moderate range of densities found in San Diego Bay (Reusch \& Williams 1998). The sediment surface of each experimental plot was plowed with bare hands and all resident mussels were carefully removed before adding the experimental individuals. I avoided excavating and sieving the sediment in order to leave the eelgrass plants intact. Only where the polyethylene mesh fabric rings were inserted were some rhizomes disturbed, which, however, did not lead to plant mortality. Mussel individuals $<10 \mathrm{~mm}$ in length could not be quantitatively removed prior to the addition of the experimental individuals and were therefore not considered for the calculation of the mortality rates.

To address the hypothesis that byssal cocoons may protect Musculista senhousia against predation (Morton 1974), the cocoons were either carefully removed 
Table 1. Mortality rate experiments (MRE) and predator exclusion experiment to assess sources of mortality in Musculista senhousia, in particular the contribution of predation, in San Diego Bay, California. The objectives were to assess (1) sources of mortality in $M$. senhousia, (2) the effects of presence or absence of a byssal bag, (3) the effects of presence or absence of an eelgrass bed, and (4) the effects of site on the mortality rates of $M$. senhousia through predation. In the predator exclusion experiment, in addition to the above objectives, the effects of predator exclusion (objective 5) were tested on $M$. senhousia survival

\begin{tabular}{|c|c|c|c|c|c|c|}
\hline $\begin{array}{l}\text { Expt } \\
\text { (objectives) }\end{array}$ & $\begin{array}{c}\text { Start date } \\
\text { (duration, wk) }\end{array}$ & Site & $\begin{array}{l}\text { Predator } \\
\text { exclusion }\end{array}$ & Habitat & $\begin{array}{l}\text { Byssal bag } \\
\text { treatment }\end{array}$ & $\begin{array}{l}\text { Replication } \\
\text { (no. experi- } \\
\text { mental units) }\end{array}$ \\
\hline $\begin{array}{l}\text { MRE } 1 \\
(1,2,3)\end{array}$ & $\begin{array}{c}12 \mathrm{Jul} 1995 \\
\text { (2) }\end{array}$ & Harbor Island & None & $\begin{array}{l}\text { Large clearing, } \\
\text { inside eelgrass }\end{array}$ & $\begin{array}{c}\text { Byssal bag, } \\
\text { no bag }\end{array}$ & $\begin{array}{c}4 \\
(16)\end{array}$ \\
\hline $\begin{array}{l}\text { MRE } 2 \\
(1,2,3)\end{array}$ & $\begin{array}{l}3 \text { Aug } 1995 \\
\text { (2) }\end{array}$ & Harbor Island & None & $\begin{array}{l}\text { Large clearing, } \\
\text { inside eelgrass }\end{array}$ & $\begin{array}{l}\text { Byssal mat, } \\
\text { byssal bag, } \\
\text { no bag }\end{array}$ & $\begin{array}{c}4 \\
(24)\end{array}$ \\
\hline $\begin{array}{l}\text { MRE 3 } \\
(1,2,3)\end{array}$ & $\begin{array}{l}3 \text { Oct } 1995 \\
\text { (2) }\end{array}$ & Harbor Island & None & $\begin{array}{l}\text { Large clearing, } \\
\text { inside eelgrass }\end{array}$ & $\begin{array}{l}\text { Byssal mat, } \\
\text { byssal bag, } \\
\text { no bag }\end{array}$ & $\begin{array}{c}4 \\
(24)\end{array}$ \\
\hline $\begin{array}{l}\text { MRE } 4 \\
(1,3,4)\end{array}$ & 22 Sep 1995 & $\begin{array}{l}\text { Harbour Island, } \\
\text { Le Meridien }\end{array}$ & None & $\begin{array}{l}\text { Sand flat, } \\
\text { inside eelgrass }\end{array}$ & Byssal mat & $\begin{array}{c}5 \\
(20)\end{array}$ \\
\hline $\begin{array}{l}\text { Predator } \\
\text { exclusion } \\
\text { experiment } \\
(3,5)\end{array}$ & $\begin{array}{c}5 \text { Dec } 1995 \\
\text { (17) }\end{array}$ & Harbor Island & $\begin{array}{c}\text { Partial cage, } \\
\text { complete cage, } \\
\text { none }\end{array}$ & $\begin{array}{c}\text { Sand flat } \\
\text { shallower/deeper } \\
\text { than eelgrass, } \\
\text { inside eelgrass }\end{array}$ & Byssal bag & $\begin{array}{c}7 \\
(42) \\
(+14 \text { controls })\end{array}$ \\
\hline
\end{tabular}

from the mussels with scissors or left intact. In MRE 2 and 3, I also used a third byssal cocoon treatment in which mussels not only retained their cocoon but were transplanted within an intact sediment core as a byssal mat. In this third byssal cocoon treatment, counting of individuals within the intact sediment core was not possible before the experiment. I tried to match the mussel abundance presented in the other 2 treatments by using an appropriate core size $\left(45 \mathrm{~cm}^{2}\right)$. The mean mussel number within $N=10$ cores of $45 \mathrm{~cm}^{2}$ taken in the source bed was $17.3 \pm 0.8$ (SE) individuals, which is slightly higher than 15 , the number of pre-counted individuals in the other 2 byssal bag treatments. In MRE 4, $M$. senhousia transplants consisted only of a core of $45 \mathrm{~cm}^{2}$ of intact byssal mat. In the source bed only a few $(2 \%)$ drilled individuals were already present in the population and none were crushed $(N=150$ $M$. senhousia); thus any bias with the estimated contribution of Pteropurura festiva to mortality during the experiment was small.

Upon termination of the experiments, I sifted the sediment of each experimental unit through a $1 \mathrm{~mm}$ mesh size, and collected and measured all living Musculista senhousia and dead shells. Dead individuals were only counted as recovered if both valves were present. Counts of recovered mussels were categorized as follows: (1) with tubular drill hole, thus eaten by Pteropurpura festiva; (2) crushed, thus eaten by crustacean predators; (3) missing, thus either lost through deployment/sampling or eaten and removed from plot by predators; (4) dead and undamaged; (5) living. Counts were transformed into fractions of the total number of transplanted $M$. senhousia in MRE 1 to 3. In MRE 4, I calculated fractions based on the estimated average number of individuals transplanted within a core of $45 \mathrm{~cm}^{2}$ (i.e. 17.3)

The categorized fractions were subjected to analysis of variance (ANOVA). In MRE 1 to 3 , which were analyzed together, the factors 'byssal bag treatment' and 'clearing vs eelgrass bed' were fully crossed. My objective in using 3 experimental dates was not to consider them as a true random subsample of all possible dates, the implicit assumption in an ordinary mixed model ANOVA, but to increase the power of the experiment. Therefore, I nested both fixed factors 'byssal cocoon' and 'clearing vs eelgrass bed' in the random factor 'date' (Mckone 1993). This allows an evaluation of the average effects of the experimental factors over all 3 dates by dividing their variance component through $\mathrm{MS}_{\text {error. }}$ Heterogeneity of variances (assessed graphically in group mean vs variance plots) could not be completely removed but was decreased through angular transformation. In MRE 4, the effects of 'site' and 'inside/outside of eelgrass bed' on the different recovered fractions of $M$. senhousia were analyzed using 2 factor ANOVA with the fixed factor inside/outside of eelgrass bed' nested in 'site'.

Predator exclusion experiment on survival of Musculista senhousia over 4 mo. In order to assess differences in $M$. senhousia survival with and without 
predators over a longer time interval, I placed precounted $M$. senhousia in caged and partially caged plots for a period of $4 \mathrm{mo}$. Twenty-three $M$. senhousia individuals (size range 10 to $28 \mathrm{~mm}$ ) were deployed on 5 December 1995 as in the MRE. The circular experimental units were either protected by complete cages (mesh size $10 \mathrm{~mm}$, gauge size $2 \mathrm{~mm}$ ) or the access to predators was allowed through 3 holes of $12 \mathrm{~cm}$ (width) $\times 6 \mathrm{~cm}$ (height) at the above-sediment base of the cage. Cages extended $15 \mathrm{~cm}$ into the water column, thus to $\leq 1 / 3$ the height of the average plants, and possessed a conical roof. The mesh size was large enough to allow the eelgrass leaf shoots and rhizome tips to grow through the fabric. As a control treatment for cage effects, additional uncaged plots surrounded by buried fences similar to those used in the MRE were set-up shallower and deeper than the eelgrass bed (thus $N=7,14$ experimental units). Caged, incompletely caged and uncaged control plots were grouped in blocks approximately $30 \mathrm{~cm}$ from each other. Blocks $(\mathrm{N}=7)$ were randomly placed along $50 \mathrm{~m}$ depth contours within $(1.5$ to $2 \mathrm{~m}$ depth), deeper (3.5 $\mathrm{m}$ depth) and shallower (0.5 to $0.8 \mathrm{~m}$ depth) than the eelgrass bed. Upon termination of the experiment, mussels were retrieved, sifted and categorized as in the above experiments. In contrast to the MRE, it was not possible to ascribe sources of $M$. senhousia mortality in this experiment because shells decay quickly. In a laboratory experiment in which freshly killed mussels were left in natural sediments from Harbor Island under flow through of San Diego Bay water, the shells of $M$. senhousia started to disintegrate in 10 from 24 individuals after only $4 \mathrm{wk}$ (author's unpubl. data). Hence, I only analyzed the number of surviving individuals with 3-way ANOVA including the orthogonal factors 'inside/outside of eelgrass bed' and 'predator presence/absence'. Blocks were nested in 'inside/outside of eelgrass bed'.

Outdoor aquarium experiments on the feeding preference of the snail Pteropurpura festiva. Preliminary field observations never revealed $P$. festiva feeding on bivalves other than Musculista senhousia, although several native bivalve species such as Chione undatella and levicardium substriatum co-occurred with $M$. senhousia, albeit at much lower abundances (author's unpubl. data). In order to decide whether the apparent preference of $P$. festiva for $M$. senhousia was due to the numerical dominance of the introduced mussel over native bivalves or due to a real preference for the non-native mussel, I assessed the feeding preference of $P$. festiva between introduced $M$. senhousia and a native clam, C. undatella, in aquarium trials. $C$. undatella was chosen because it lives at the same sediment depth than $M$ senhousia, is a natural prey item of $P$. festiva in southern California (Peterson 1982) and is the second most abundant bivalve at several sites in southern California lagoons (author's pers. obs., J A. Crooks pers. comm.).

The experiments were conducted in ambient light and temperature in 8 outdoor aquaria of $48 \times 24 \times$ $21 \mathrm{~cm}$ (length $\times$ width $\times$ height). Each aquarium was filled with washed sand from San Diego Bay to a height of $8 \mathrm{~cm}$ and had a separate water inflow of approximately $11 \mathrm{~min}^{-1}$. Mussels and clams were collected from San Diego Bay $\left(32^{\circ} 44.3^{\prime} \mathrm{N}, 117^{\circ} 12.6^{\prime} \mathrm{W}\right)$ and kept in a large tub $(75 \times 50 \mathrm{~cm}, 10 \mathrm{~cm}$ sediment depth) under flow through of ambient San Diego Bay water. The bivalves were not starving and grew as well within the tanks as in the field (author's unpubl. data).

In a first set of choice experiments, I placed equal numbers of Chione undatella and Musculista senhousia (10 individuals each) representing their natural size distribution found at the collecting site into an area of $300 \mathrm{~cm}^{2}$. M. senhousia possessed their byssal bag but were not within byssal mats, which is typical for low to moderate densities in the field $\left(<1000\right.$ ind. $\left.\mathrm{m}^{-2}\right)$. The mean standard length of $C$. undatella and $M$. senhousia $( \pm \mathrm{SE})$ was $29.4 \pm 2.0 \mathrm{~mm}$ and $16.8 \pm 0.25 \mathrm{~mm}$, respectively, which is significantly different in a $t$-test $(t=14.2, \mathrm{p}<0.0001)$. After $1 \mathrm{~d}, \mathrm{I}$ added one Pteropurpura festiva (mean length $54 \pm 4 \mathrm{~mm}$ ) to each aquarium. I conducted 15 runs without prey replacement for periods of 24 to $70 \mathrm{~h}$, during which no more than 5 bivalves were eaten. In a second set of experiments $(\mathrm{N}=15)$, I matched the standard lengths of both species to exclude a potential size bias in the decision of the snail. Mean shell lengths \pm SE were $16.8 \pm 0.25 \mathrm{~mm}$ and $17.92 \pm 0.5 \mathrm{~mm}$ for $M$. senhousia and C. undatella, respectively, a difference which was not significant in a $t$-test

The preference of Pteropurpura festiva was assessed under the assumption that autogenic changes in prey abundance can be neglected (Peterson \& Renaud 1989). This assumption was justified because (1) in all 30 experimental runs, only 5 from 343 bivalves died from sources other than predation, and (2) all predation events can be unambiguously assigned to $P$. festiva by virtue of a drill hole. The statistical significance of the prey preference was assessed with a $2 \times 2$ contingency table.

In equally sized individuals of different bivalve species, the preference of predators for one species may be influenced by different flesh content, thus energy gain, and/or by different shell thickness, corresponding to longer handling times. Therefore, I also measured the shell length, the shell thickness, and the dry flesh mass of a subsample of 50 individuals in both species. Differences in shell thickness and dry flesh mass as a function of individuals size were compared between the 2 species with ANCOVA. 


\section{RESULTS}

\section{Mortality rate experiments (MRE) to assess per capita mortality rates of Musculista senhousia}

Over the 2 to $4 \mathrm{wk}$ experimental exposure, a substantial fraction of Musculista senhousia was consumed by predators. Snails Pteropurpura festiva were the single most important mortality source for $M$. senhousia ( $\mathrm{N}_{\text {drilled }} / \mathrm{N}_{\text {drilled+crushed+dead }}$ ) in MRE 1, 2 and 4 . On average, consumption by $P$. festiva accounted for 77 , 71,21 and $42 \%$ of the total mortality in MRE 1 to 4 respectively. The associated per capita mortality rates $\left(\mathrm{N}_{\text {drilled }} / \mathrm{N}_{\text {transplanted }}\right)$ attained a maximum of $0.65 \pm$ 0.22 ind. $/ 2 \mathrm{wk}$ (Fig. 1) and $0.7 \pm 0.1$ ind. $/ 4 \mathrm{wk}$ (Fig. 2) in MRE 2 and 4, respectively, both within eelgrass beds. In MRE $4, M$. senhousia suffered lower mortality rates at LM compared to $\mathrm{HI}$, albeit of the same order of magnitude (Fig. 2). Average mortality rates over $4 \mathrm{wk}( \pm \mathrm{SE}$ ) due to $P$. festiva were $0.19 \pm 0.09$ and $0.37 \pm 0.12$ at LM and $\mathrm{HI}$, respectively, a difference which is significant in an ANOVA ( $\left.\mathrm{N}_{\text {drilled }} / \mathrm{N}_{\text {transplanted }}, F_{1,14}=5.2, \mathrm{p}=0.039\right)$. In all MRE, only 6 and 4 dead individuals, respectively, could be attributed to shell-crushing predators in MRE 1 and 2, corresponding to per capita rates of 0.012 and $0.018 / 2 \mathrm{wk}$. As potential crustacean candidates for the consumption of $M$. senhousia, I often observed individuals of Panulirus interruptus near or in the experimental patches at both sites, HI and LM.

In MRE 1 to 3, which had treatments with precounted mussels, on average 14.5 of the 15 trans-

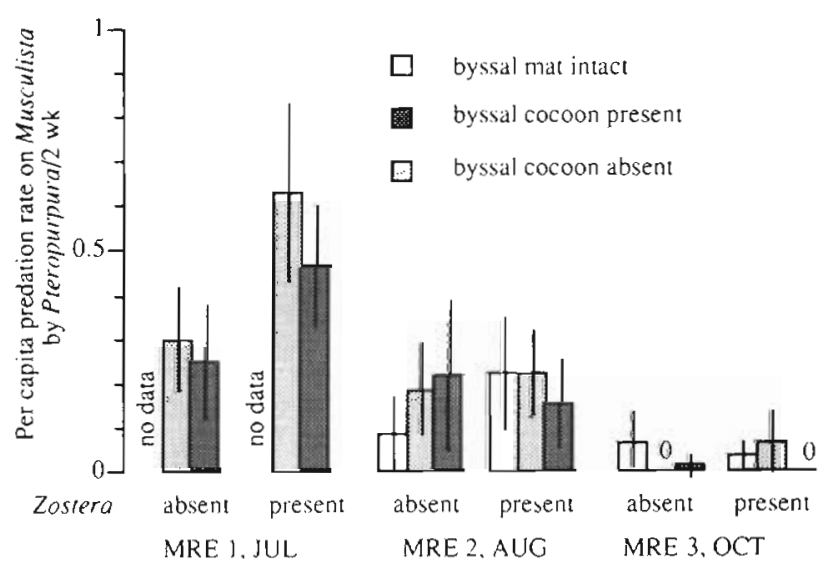

Fig. 1. Per capita mortality rates ( $\pm 1 \mathrm{SE}$ ) of Musculista senhousia through predation by a muricid snail (Pteropurpura festiva) during three $2 \mathrm{wk}$ mortality rate experiments (MRE). $M$. senhousia were either transplanted in a sediment core ('byssal mat intact'), planted singly within their cocoon ('byssal cocoon present'), or planted after experimental removal of bag ('byssal cocoon absent'). 'Zostera present/ absent' refers to large, unvegetated clearings within the $Z$. marina bed vs locations inside the eelgrass bed. For statistical analysis see Table 2

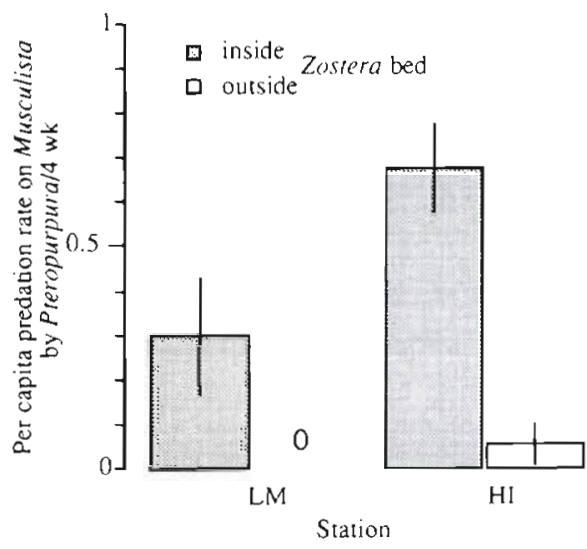

Fig. 2. Per capita mortality rates of Musculista senhousia ( $\pm 1 \mathrm{SE}$ ) through Pteropurpura festiva predation during MRE 4 conducted at 2 sites over $4 \mathrm{wk}$. All mussels were transplanted within an intact byssal mat to either inside a closed canopy eelgrass bed or on the adjacent sand flat $>2 \mathrm{~m}$ away from any vegetation. LM: Le Meridien; HI: Harbor Island. Outside eelgrass at LM, all mussel individuals in 2 replicates died from an overlying thallus of a drifting giant kelp Macrocystis pyrifera and therefore had to be excluded from the analysis

planted mussels (i.e. 96\%) were recovered upon termination of the experiments. The non-recovered fraction of $4 \%$ represented the maximal fraction of individuals which were removed and eaten by predators other than Pteropurpura festiva. In MRE 4, $15.8 \pm$ 1.4 individuals were recovered on average after $4 \mathrm{wk}$, i.e. $91 \%$ of an estimated number of 17.3 transplanted mussels per plot. Hence, the fraction of individuals attributable to either predation with removal from the plots or due to sampling error was $9 \%$.

In all experiments, predation pressure ascribable to snails differed among vegetated and unvegetated habitats. Contrary to expectations, the mortality rates through snail predation averaged over MRE 1 to 3 were $38 \%$ higher within the eelgrass than in unvegetated clearings, which was significant in an ANOVA (Table 2). The significant outcome of the main effect, 'clearing vs eelgrass bed', is mainly attributable to MRE 1 and 2, while in MRE 3, predators, in particular Pteropurpura festiva, foraged only a little in all experimental plots (Fig. 2). In MRE 4, where I compared sand flats outside a continuous eelgrass bed with locations inside the vegetation, $12 \times$ more mussels were consumed within the Zostera marina bed compared to outside, averaged over both locations (response variable $\mathrm{N}_{\text {dnlled }} / \mathrm{N}_{\text {transplanted, }}$ factor 'inside/outside eelgrass bed', $F_{1,14}=13.4, \mathrm{p}=0.0006$ ).

Contrary to expectations, the presence of a byssal bag either singly or within a byssal carpet did not decrease the predation mortality of Musculista senhousia due to Pteropupura festiva and was not significant in the statistical analysis (Table 2). 
Table 2. Analysis of variance: effects of date, byssal cocoon treatment and eelgrass (unvegetated clearing vs eelgrass bed) on per capita mortality rates of Musculista senhousia due to predations by snails Pteropurpura festiva. The factor 'byssal cocoon' has 3 levels: byssal cocoon absent, byssal cocoon present, and byssal cocoon present withir an intact byssal mat. The ANOVA model has a nested structure in which the fixed factors 'byssal cocoon' and 'clearing vs eelgrass bed' are nested in 'date', which is considered random (cf. McKone 1993). This allows testing of the effects of interest through $\mathrm{MS}_{\text {restiual. }}$ Three plots in MRE 2 and another 3 plots in MRE 3 could not be relocated; thus the experimental design became unbalanced

\begin{tabular}{|lrllll|}
\hline Source of variation & df & MS & $F$ & p \\
\hline Date & 2 & 2.160 & 56.60 & 0.0004 \\
Byssal cocoon treatment (Date) & 5 & 0.0132 & 0.143 & 0.981 \\
Clearing vs eelgrass bed (Date) & 3 & 0.264 & 2.873 & 0.047 \\
Byssal cocoon $\times$ eelgrass (Date) & 5 & 0.038 & 0.415 & 0.836 \\
Residual & 43 & 0.092 & & \\
& & & &
\end{tabular}

\section{Predator exclusion experiment over 4 mo}

The exclusion of predators had a highly significant effect on Musculista senhousia survival over a period of $4 \mathrm{mo}$ (Fig. 3). These results support the outcomes of the MRE, in particular of MRE 4, where the same habitat types were compared (inside/outside eelgrass bed). Similar to the marked habitat differences in MRE 4, $22 \times$ more mussels survived on the flat outside the eelgrass bed (mean no. survivors shallower/deeper sand flat) than inside the meadow if predators were present in the plots. The differences in predation pressure inside vs outside the eelgrass bed was statistically supported in an ANOVA by a significant interaction term

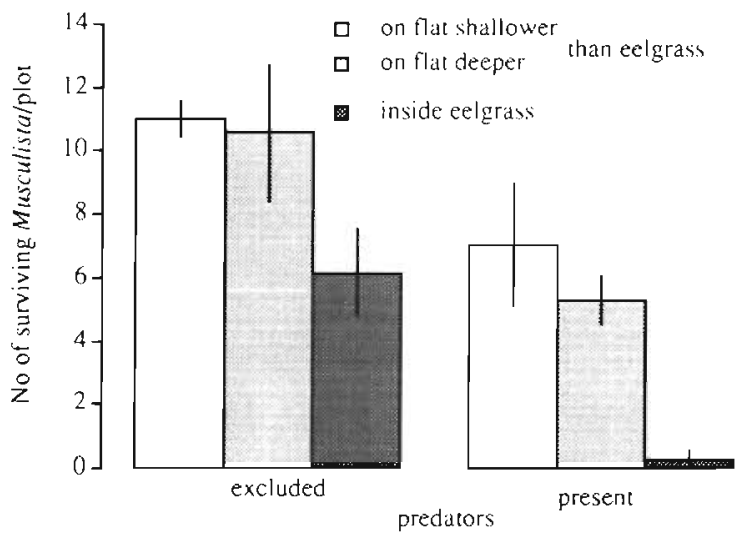

Fig. 3. Number of surviving Musculista senhousia ( $\pm 1 \mathrm{SE}$ ) after 4 mo experimental exposure inside and outside an eelgrass bed and with or without predators at $\mathrm{HI}(\mathrm{N}=7)$. Only data from the main experiment (partial and full cages) are given. Twenty-three mussel individuals were initially transplanted to each plot. For statistical analysis see Table 3
Table 3. Analysis of variance: comparison of the number of surviving Musculista senhousia in plots of $300 \mathrm{~cm}^{2}$ from December 1995 to March 1996 inside and outside eelgrass and with and without predators. Data were $\log (x+1)$-transformed to reduce heteroscedasticity. Inside/outside of eelgrass had 3 levels: experimental units were placed shallower and deeper than the eelgrass bed on the sand flat and inside the eelgrass bed at $\mathrm{HI}$

\begin{tabular}{|lrcccc}
\hline Source of variation & df & MS & $F$ & $p$ \\
\hline Inside/outside of eelgrass bed & 2 & 1.137 & 24.48 & $<0.0001$ \\
Predator presence/absence & 1 & 1.760 & 37.93 & $<0.0001$ \\
Eelgrass $\times$ Predators & 2 & 0.248 & 4.879 & 0.0203 \\
Block (Eelgrass) & 18 & 0.051 & 1.096 & 0.424 \\
Residual & 18 & 0.046 & & \\
\hline
\end{tabular}

'inside/outside eelgrass bed $\times$ predator presence/ absence' (Table 3). The main effect 'inside/outside of eelgrass' was significant ds well indicating additional mortality other than predation inside the eelgrass bed (Fig. 3, Table 3).

I underestimated the effects of predator exclusion in this experiment because I found a total of 14 individuals eaten by snails inside complete cages $(=0.66$ drilled shells/complete cage). Pteropurpura festiva were obviously able to reach with their proboscis through the cage meshes and prey on individuals adjacent to the cage walls.

In a control experiment I compared mussel survival between completely uncaged treatments (with buried fences) and the partial cages. No artifacts of the aboveground cage structures were detectable on the number of surviving Musculista senhousia $\left(\mathrm{MS}_{\mathrm{error}}=23.0\right.$ effect 'cage': $F_{1.24}=0.125, \mathrm{p}=0.7$; interaction 'cage $\times$ habitat': $F_{1,24}=0.349, \mathrm{p}=0.56$ ).

\section{Feeding preference of Pteropurpura festiva}

Pteropurpura festiva preferred Musculista senhousia over Chione undatella (Table 4). This applied to experiments in which the size composition of the 2 bivalve species was dissimilar but representative of the natural size distribution, as well as to experiments where both prey species had similar shell lengths. However, the preference of $P$. festiva for $M$. senhousia was less pronounced when both species were offered at equal mean sizes. For individuals similar in shell length, shells were approximately $5 \times$ thicker in C. undatella than in $M$. senhousia (ANCOVA, response variable 'shell thickness', effect species $\times$ shell length, $p=$ 0.0001 ), suggesting that the drilling time of $P$. festiva for $C$. undatella would be longer than for $M$. senhousia. In contrast, no difference in the amount of dry flesh mass was detectable between $C$. undatella and $M$. sen- 
Table 4. Feeding preference of the snail Pteropurpura festiva if offered a choice between equal numbers of the introduced Musculista senhousia and native co-occurring Chione undatella. Fifteen runs were performed in both experiments. The significance of the feeding preference was tested with a $2 \times 2$ contingency table

\begin{tabular}{|lccccc|}
\hline Expt & \multicolumn{2}{c}{$\begin{array}{c}\text { No. of } M \text {. senhousia } \\
\text { Offered }\end{array}$} & \multicolumn{2}{c|}{$\begin{array}{c}\text { No. of C. undaten } \\
\text { Effered }\end{array}$} & Eaten \\
\hline Choice between populations in natural size distribution & 172 & 43 & 150 & 0 & $<0.0001$ \\
Choice between equal sizes & 171 & 16 & 148 & 3 & 0.018 \\
\hline
\end{tabular}

housia of equal shell length (ANCOVA, response variable 'dry tissue mass', effect 'species $\times$ shell length'. $p=0.17$, pintercept $=0.66$ )

\section{DISCUSSION}

In this study experimental evidence is presented that native predators are responsible for a significant mortality in populations of the invasive bivalve Musculista senhousia. Short-term experiments in a southern California bay during which precounted $M$. senhousia were exposed for 2 to $4 \mathrm{wk}$ to ambient predator densities revealed that up to $65 \%$ of the transplanted mussels were consumed by a muricid snail (Pteropurpura festiva) within only $2 \mathrm{wk}$. In a 4 mo predator exclusion experiment, mussel survival rates were reduced by half in the presence of predators compared to predator exclusion treatments. To my knowledge, this is the first experimental demonstration in marine ecosystems that the abundance of a potentially dominant non-indigenous species, such as $M$. senhousia, is locally controlled through native predators. $M$. senhousia was not only consumed by native predators, but even preferred over at least 1 native bivalve species by the most conspicuous predator, $P$. festiva.

To my surprise, I found predation to be more intense inside an eelgrass bed at both experimental sites, contrary to many other studies which identified seagrass beds as refuges for bivalves and other invertebrates against predation (Olafsson et al. 1994). The observed increase in predation mortality among vegetated vs unvegetated habitats was moderate $(38 \%)$ when comparing locations inside the eelgrass bed with large clearings. When comparing sand flat habitats situated completely outside the eelgrass bed with locations inside the eelgrass, mortality rates inside the vegetation bed were 12 to $22 \times$ higher.

Only 1 of 27 experimental studies reviewed by Ólafsson et al. (1994) identified epibenthic predators to reduce the abundance of infaunal invertebrates in vegetated habitats, assessed as significant outcomes in predator exclusion experiments. Peterson (1979) argued that the exclusion of epibenthic predators inside aquatic vegetation has only weak effects on invertebrate survival rates because submerged vegetation already offers protection against predators. This study not only revealed significant predation effects inside an eelgrass (Zostera marina) bed through experimental exclusion of epibenthic predators; it also showed that predation effects were much stronger inside the vegetation compared to adjacent areas without eelgrass.

My intention in this study was not to assess the direct effects of the presence or absence of aquatic vegetation on the foraging efficiency of the predator species. Rather, I wanted to assess habitat specific differences in predation mortality of Musculista senhousia. Some studies, notably on fish and shrimp predation on crustaceans (e.g. Nelson 1979) and on burrowing predators preying on bivalves (e.g. Blundon \& Kennedy 1982), provide mechanistic explanations of why invertebrate prey is protected from predation within seagrass beds (overview in Heck \& Crowder 1991).

At this point it is unclear why the present results deviate from the general pattern identified in vegetated habitats (Ólafsson et al. 1994). That the eelgrass beds in San Diego Bay offer little protection for bivalves from burrowing predators (Blundon \& Kennedy 1982) is not surprising, given that shoot densities are comparatively low and a rhizome mat is poorly developed (author's unpubl. data). Furthermore, Musculista senhousia lives just below the sediment surface and Pteropurpura festiva is able to prey on mussels without burrowing by means of its extendable proboscis. Probably, the observed enhancement of predation inside the vegetation is an indirect effect. One reasonable speculation awaiting further study is that $P$. festiva preferred eelgrass beds over sand flats to forage because the vegetation provides shelter against higher order predators.

Contrary to my expectations, I found no difference in mortality rates among Musculista senhousia where the byssal bag was experimentally removed compared to unmanipulated individuals. Even if predation rates on $M$. senhousia inside cocoons or byssal mats are lower compared to cocoon-free individuals, those differences may have remained undetected in the performed $2 \mathrm{wk}$ 
experiments if the additional time the snails needed to consume mussels inside cocoons or byssal mats is short relative to the experimental duration. Feeding trials in aquaria where individuals with and without bags are placed close to one another are desirable to clearly define the role of byssal bags for the survival of $M$. senhousia.

In all experiments only small numbers of mussels were transplanted, raising the concern that mortality rates on such small prey numbers may not be a sensible reflection of the existing predation rates. Previous experiments addressing effects of Musculista senhousia on eelgrass revealed that snails were also able to markedly reduce the abundance of $M$. senhousia in approximately $20 \times$ larger mussel patches which had a $5 \times$ higher mussel density than in this study (Reusch \& Williams 1998). Within $0.5 \mathrm{~m}^{2}$ large $M$. senhousia patches ( 4000 ind. $\mathrm{m}^{-2}$ ), 41 and $77 \%$ of the individuals were consumed inside an eelgrass bed after 4 and 6 mo, respectively.

In all $M R E$, conducted over $\leq 4 w \mathrm{k}$, the contribution of the muricid snail Pteropurpura festiva to Musculista senhousia mortality could be reliably estimated because snails leave a cylindrical drill hole in the mussel shell, allowing differentiation from countersunk holes left by Conus californicus, which were occasionally found at LM. Moreover, P. festiva never removed individuals from the plots in aquarium trials (author's unpubl. data). Most of the crushed individuals were opened at the anterior tips, which were completely bitten off, an indication of lobster Panulirus interruptus predation. However, qualitative feeding experiments in aquaria indicated that lobsters sometimes crushed M. senhousia completely. From the percentage of crushed shells relative to all freshly dead individuals I conclude that crustaceans contributed $\leq 6 \%$ to $M$. senhousia's total mortality. Predation rates by crustaceans may have been underestimated if they had crushed the shells entirely and/or removed their prey from the experimental plot. Fish predation may also play a significant role for mussel mortality given that several species of near shore fishes were found to have small M. senhousia in their guts (Anisotremus davidsoni, Umbrina roncador, Roncador stearnsii; Crooks 1992). Because most of the individuals were tecovered in the MRE, no more than $4 \%$ of $M$. senhousia in MRE 1 to 3 and $9 \%$ in MRE 4 could have been eaten by fishes, the number of individuals which could not be recovered either dead or alive.

Musculista senhousia possesses several life history traits which allow this bivalve to persist even in the face of high per capita predation rates. With yearly von Bertalanfy growth constants $k$ from 0.39 to $0.90, M$. senhousia grows quickly compared to other mytilid bivalves (Crooks 1996). This way, the species is able to remain spatially dominant even if mortality rates are relatively high, as demonstrated by Reusch \& Chapman (1997) for blue mussels. Secondly, recruitment of $M$. senhousia can be very high, with densities up to 23000 ind. $\mathrm{m}^{-2}$ reported by Kikuchi \& Pérez (1977). Some patches of juveniles within the shallow subtidal may reach 160000 ind. $\mathrm{m}^{-2}$ (Crooks 1998). Intense episodes of recruitment may swamp mussel predators, especially if they vary unpredictably in space and time.

In San Diego Bay, predation is not the only mechanism of biotic invasion resistance that populations of Musculista senhousia meet in southern California. As a second important effect, the presence of an continuous eelgrass canopy may prevent $M$. senhousia from becoming dominant and forming habitat-altering byssal carpets within eelgrass beds. $M$. senhousia grew more slowly and mortality rates other than predation were greater inside extended eelgrass beds compared to open sand flats. Mussels received less food and starved inside the canopy (Reusch \& Williams in press), although $M$. senhousia has been reported as constituent faunal element in Zostera spp. beds in Japan and Siberia (Kikuchi \& Perez 1977, and references therein). This mechanism of invasion resistance depends on the spatial arrangement of the eelgrass beds (i.e. continuous vs patchy beds), and on the hydrodynamic regime at the sites. At sites where mussel predators occur and extended (as opposed to patchy) eelgrass beds are present, 2 mechanisms of invasion resistance act in concert. Simultaneously, extended eelgrass beds indirectly enhance the predation. mortality for $M$. senhousia and reduce $M$. senhousia survival by decreasing the food supply to the mussel.

To date, few studies have addressed negative biotic effects, ecological resistance sensu Elton (1958), on established non-native species which may control population growth and hence, indirectly, potential community-level effects of the invaders. In the only published experimental study in the marine environment, Trowbridge (1995) found no indication that grazing on invasive Codium fragile $\mathrm{f}$. tomentosoides by native gastropods would preclude further spread and proliferation of the non-indigenous alga. Willan (1987) reported that in New Zealand, where Musculista senhousia also established populations in the 1970s, several species of native snails could potentially consume the non-indigenous bivalve. Yet, no trace of predation such as drilled shells was found at that time. It would be interesting to investigate now, 20 yr after the New Zealand introduction, if snails have begun consuming $M$. senhousia there too. The introduction of $M$. senhousia to San Diego Bay occurred approximately one decade earlier than in New Zealand and $M$. senhousia has markedly increased its biomass only during the past 10 yr (Dexter 1983, Crooks pers. comm.). Time 
lags of native predators to introductions of novel prey species have been observed in terrestrial biotas (e.g. Southwood 1961) and in waterfowl feeding on an invasive freshwater bivalve, Dreissena polymorpha (Suter 1982). It is therefore tempting to speculate that it takes native predatory snails several years to discover $M$. senhousia as an attractive new prey species. At my study sites, I also observed snails laying numerous egg cases throughout the year. Regular temporal sampling may reveal whether Pteropurpura festiva currently increases numerically as a response to abundant prey in San Diego Bay. If so, this may extend the area where $M$. senhousia is prevented from forming dominant, habitat-modifying beds in southern California bays.

Acknowledgements. I thank Susan L. Williams for support and for everything I learned during the stay in her lab. Comments of A. Albrecht, J. A. Crooks and 4 anonymous reviewers improved earlier versions of the manuscript. The help of the divers B. Allen, K. Bickel, Thilo Reusch, C. Schönberg, A. Sewell, J. Sibley, C. Taylor made this study possible. Thanks to J. Sibley and A.-C. Bockelmann for accurate lab assistance. This project was funded by a NATO-stipend through the German Academic Exchange Service (DAAD) and through a grant of the Deutsche Forschungsgemeinschaft (Re 1108/2-3) to T.R. Further financial support came from the College of Sciences at San Diego State University (SDSU), which provided logistical support. This is contribution \#290 from the Coastal Marine Institute at SDSU.

\section{LITERATURE CITED}

Baltz DM, Moyle PB (1993) Invasion resistance to introduced species by a native assemblage of California stream fishes. Ecol Appl 3:246-255

Blundon JA, Kennedy VS (1982) Refuges for infaunal bivalves from blue crab Callinectes sapidus (Rathburn) predation in Chesapeake Bay. J Exp Mar Biol Ecol 65:67-81

Carlton JT (1979) History, biogeography, and ecology of the introduced marine and estuarine invertebrates of the Pacific coast of North America. Dissertation, University of California at Davis

Case JT (1991) Invasion resistance, species built up, and community collapse in metapopulation models with inter-species competition. Biol J Linn Soc 42:239-266

Creese R, Hooker S, de Luca S, Wharton Y (1997) Ecology and environmental impact of Musculista senhousia (Mollusca: Bivalvia: Mytilidae) in Tamaki Estuary, Auckland, New Zealand. NZ J Mar Freshwat Res 31:225-236

Crooks JA (1992) The ecology of the introduced bivalve, Musculista senhousia, in Mission Bay, San Diego. Master's thesis, San Diego State University

Crooks JA (1996) The population ecology of an exotic mussel, Musculista senhousia, in a Southern California Bay. Estuaries 19:42-50

Crooks JA (1998) Habitat alteration and community-level effects of an exotic mussel Musculista senhousia. Mar Ecol Prog Ser 162:137-152

Dexter DM (1983) Soft bottom infaunal communities in Mission Bay. Calif Fish Game 69:5-17

Elton CS (1958) The ecology of invasion of animals and plants. John Wiley \& Sons, New York

Heck KL Jr, Crowder LB (1991) Habitat structure and preda- tor-prey interactions in vegetated aquatic systems. In: Bell SS, MCCoy ED, Mushinsky HR (eds) Habitat structure. The physical arrangement of objects in space. Chapman and Hall, London, p 281-299

Hoenselaar HJ, Hoenselaar J (1989) Musculista senhousia (Benson in Cantor, 1842) in the Western Mediterranean (Bivalvia, Mytilidae). Basteria 53:73-76

Kikuchi T, Pérez JM (1977) Consumer ecology of seagrass beds. In: McRoy CP, Helfferich C (eds) Seagrass ecosystems. A scientific perspective. Marcel Dekker, New York, p $147-194$

Lodge DM (1993) Biological invasions: lessons for ecology. Trends Evol Ecol 8:133-137

MacDonald KB, Ford RF, Copper EB, Unitt P, Haltnier JP (1990) South San Diego Bay enhancement plan. Resource Atlas, Vol 1 Michael Bradman Associates Inc, San Diego

McKone MJ (1993) Statistical analysis of experiments conducted at multiple sites. Oikos 67:184-186

McLean JH (1978) Marine shells of Southern California. Natural History Museum of Los Angeles County, Los Angeles, CA

Morton B (1974) Some aspects of the biology, population dynamics, and functional morphology of Musculista senhousia Benson (Bivalvia, Mytilidae). Pac Sci 28:19-33

Nelson WG (1979) Experimental studies of selective predation on amphipods: consequences for amphipod distribution. J Exp Mar Biol Ecol 38:225-245

Olafsson EB, Peterson CH, Ambrose WG (1994) Does recruitment limitation structure populations and communities of macro-invertebrates in marine soft-bottom sediments: the relative significance of pre- and post-settlement processes. Oceanogr Mar Biol Annu Rev 32:65-109

Peterson $\mathrm{CH}$ (1979) Predation, competitive exclusion, and diversity in the soft-sediment benthic communities of estuaries and lagoons. In: Livingston RJ (ed) Ecological processes in coastal and marine systems. Plenum Press, New York, p 233-264

Peterson $\mathrm{CH}$ (1982) The importance of predation and intraand interspecific competition in the population biology of two infaunal suspension-feeding bivalves, Protothacea staminea and Chione undatella. Ecol Monogr 52:437-475

Peterson CH, Renaud PE (1989) Analysis of feeding preference experiments. Oecologia 80:82-86

Pimm SL (1989) Theories predicting success and impact of introduced species. In: Drake JA, Mooney HA, di Castri F, Groves RH, Kruger FJ, Rejmánek M, Williamsons M (eds) Biological invasions. John Wiley \& Sons, Chichester, p $351-365$

Reusch TBH (1996) Effects of the non-indigenous mussel Musculista senhousia on native eelgrass Zostera marina. In: Kuo J, Phillips RC, Walker DI, Kirkman H (eds) Seagrass biology: proceedings of an international workshop. University of Western Australia, Perth, p 269-276

Reusch TBH, Chapman ARO (1997) Persistence and space occupation of subtidal blue mussel patches. Ecol Monogr 67:65-87

Reusch TBH, Williams SL (1998) Variables responses of native eelgrass Zostera marina to a non-indigenous bivalve Musculista senhousia. Oecologia 113:428-441

Reusch TBH, Williams SL (in press) Macrophyte canopy structure and the success of a non-indigenous bivalve. Oikos

Robinson JV, Wellborn GA (1988) Ecological resistance to the invasion of a freshwater clam, Corbicula fluminea: fish predation effects. Oecologia 77:445-452

Slack-Smith SM, Brearley A (1987) Musculista senhousia (Benson 1842): a mussel recently introduced into the Swan 
River estuary, Western Australia. Rec West Aust Mus 13: $225-230$

Southwood TRE (1961) The number of species of insect associated with various trees. J Anim Ecol 30:1-8

Suter W (1982) Der Einfluß von Wasservögeln auf Populationen der Wandermuschel (Dreissena polymorpha Pall.) am Untersee/Hochrhein (Bodensee). Schweiz Z Hydrol 44: $149-161$

Trowbridge CD (1995) Establishment of the green alga Codium fragilessp. tomentosoides on New Zealand rocky

Editorial responsibility: Otto Kinne (Editor),

Oldendorf/Luhe, Germany shores: current distribution and invertebrate grazers J Ecol 83:949-965

Vermeij GJ (1991) When biotas meet: understanding biotic interchange. Science 253:1099-1104

Willan RC (1985) Successful establishment of the mussel Musculista senhousia (Benson in Cantor 1842) in New Zealand. Rec Auckland Inst Mus 22:85-96

Willan RC (1987) The mussel Musculista senhousia in Australasia: another aggressive alien highlights the need for quarantine at ports. Bull Mar Sci 41:475-489

Submitted: March 9, 1998; Accepted: June 22, 1998

Proofs received from author(s): July 20, 1998 